\title{
Agar-Gel Precipitin-Inhibition Technique for Histoplasmosis Antibody Determinations
}

\author{
JOHN G. RAY, JR. \\ Medical Sciences Laboratory, Fort Detrick, Frederick, Maryland 21701
}

Received for publication 30 January 1967

\begin{abstract}
The agar-gel precipitin-inhibition technique has been modified to detect antibodies of Histoplasma capsulatum in sera from human clinical cases and experimental animals infected with this organism. By use of this modified technique, the histoplasmosis can be detected more consistently and reliably than with the direct agar-gel diffusion test, and titers are comparable to those attained by the complement-fixation serological technique.
\end{abstract}

The complement-fixation (CF) test is the standard serological procecure for diagnosis of histoplasmosis. However, the agar-gel precipitin test has recently gained recognition as a useful serological procedure in this application.

Heiner (3), Schubert, Lynch, and Ajello (9), and Goldin and McMillen (2) have recommended macro and micro agar-gel serological tests for the diagnosis of histoplasmosis. In these studies, the direct agar-gel diffusion methods were compared with the CF method. More recently, Kaufman, Brandt, and McLaughlin (4) have compared these methods with the fluorescentantibody (FA) inhibition test and have found the agar-gel and FA procedures to be preferred, especially in anticomplementary sera suspected of containing antibodies to Histoplasma capsulatum.

Klite (5) indicated that the agar-gel test was more reactive and diagnostically more useful than the CF test in human histoplasmosis. The necessity for the concomitant use of the CF and the agar-gel precipitin tests because of the variable human antibody response to various antigens of $H$. capsulatum was, however, re-emphasized; this supports an earlier report concerning the CF test by Campbell and Binkley (1).

Unfortunately, neither the direct diffusion agar-gel nor the FA serological procedure can give titrations of sera comparable to those attained with the CF test. Moreover, CF titers of low magnitude $(1: 8$ or $1: 16)$ are negative by the FA and agar-gel techniques. This condition is similar to that observed by Ray and Kadull $(6,7)$ and Ray and Shay (8) in soluble antigen-antibody systems of anthrax, plague, and C-reactive protein, respectively, and has prompted investigation with the agar-gel precipitin-inhibition (AGPI) technique in this serological system.

\section{MATERIALS AND MethodS}

Preparation of agar-diffusion test plates and reading lamp. The medium test plates and agar diffusion reading lamp were prepared as described by Ray and Kadull (6).

$H$. capsulatum test antigens. The antigen used in this proposed serological AGPI test was obtained from the Communicable Disease Center, Atlanta, Ga., as their histoplasmin (agar-gel) precipitin lots 2 and 3, catalog number 77-1002, which corresponds to the fivefold concentration of histoplasmin employed by Schubert, Lynch, and Ajello (9).

$H$. capsulatum test antiserum. The test antiserum used routinely in the AGPI test was lots 13 and 22 human control histoplasmosis serum obtained from the Communicable Disease Center.

Box titration of the histoplasmosis antigen-antibody system. A box titration of the histoplasmosis antigen (lots 2 and 3) versus the histoplasmosis antiserum (lots 13 and 22) was performed in agar diffusion plates. Five serial twofold dilutions of the antigen ( 0.5 $\mathrm{ml})$ and of the antiserum $(0.2 \mathrm{ml})$ were prepared in physiological saline. To each dilution, an equivalent volume of physiological saline was added to give a final dilution range of $1: 2$ to $1: 32$.

The antigen dilutions were added sequentially and in duplicate to the two outer rows of wells (approximately $0.07-\mathrm{ml}$ volume per well) so that one row exactly duplicated the opposite row in serial dilutions of antigen. This was performed in five different agar diffusion plates, one for each antiserum dilution. The center row of reservoirs (approximately $0.025-\mathrm{ml}$ volume per well) was filled with one of the prepared antiserum dilutions, with the use of one plate for each dilution. Plates were incubated at room temperature $(23$ to $27 \mathrm{C})$ for $24 \mathrm{hr}$, after which the initial reading was made for the observed antigen-antibody precipitin reaction aided by the previously described visual apparatus; the final reading occurred at $48 \mathrm{hr}$.

The antigen-antibody end point was determined as that combination of the highest dilutions of antigen 
and antibody that produced a visible line of precipitate in $48 \mathrm{hr}$. This initial titration in the agar-gel plates was essential to the establishment of maximal sensitivity and consistent reproducibility in subsequent tests with unknown suspect sera. The end-point reading was arbitrarily assumed to represent a minimal reacting dilution $\left(\mathrm{MRD}_{a}\right)$ of histoplasmin antigen and a minimal reacting dilution $\left(\mathrm{MRD}_{\mathrm{s}}\right)$ of antibody to histoplasmosis (Tables 1 and 2). The $\mathrm{MRD}_{a}$ of lots
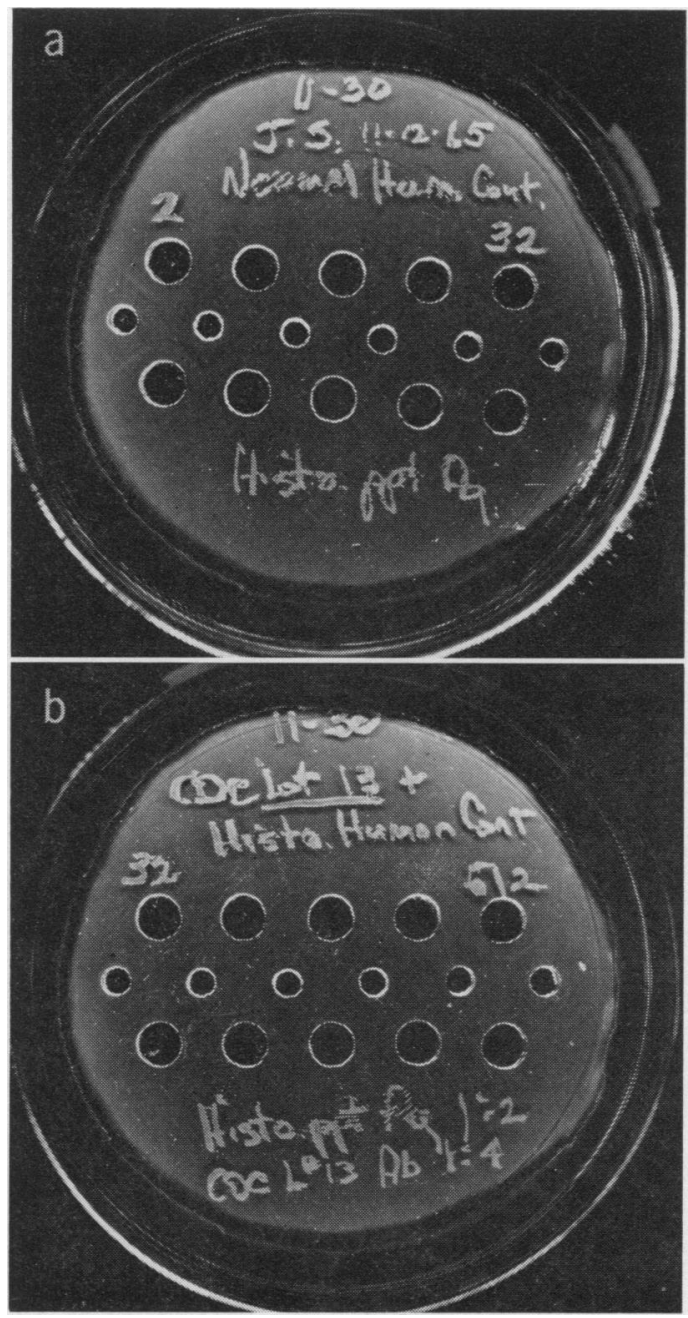

FIG. 1. Serum titrations by indirect technique. (a) Negative serum: note undulating lines of visible precipitate between center and outer rows of wells, indicating absence of binding of $M R D_{a}$. (b) Positive serum: note absence of a visible line of precipitate between the first, second, third, and fourth outer wells and the center row of wells, indicating complete binding of the $M R D_{a}$; end point is 1:256 dilution of serum.
TABLE 1. Histoplasmosis antigen-antibody agar-gel box titration ${ }^{a}$

\begin{tabular}{c|c|c|c|c|c}
\hline $\begin{array}{c}\text { Lot 13 } \mathrm{CDC}^{b} \\
\text { human control } \\
\text { dilution }\end{array}$ & \multicolumn{5}{|c}{ Lot 2 precipitin antigen dilution } \\
\cline { 2 - 5 } & $1: 2$ & $1: 4$ & $1: 8$ & $1: 16$ & $1: 32$ \\
\hline $1: 2$ & + & \pm & - & - & - \\
$1: 4$ & + & \pm & - & - & - \\
$1: 8$ & \pm & - & - & - & - \\
$1: 16$ & \pm & - & - & - & - \\
$1: 32$ & - & - & - & - & - \\
\hline
\end{tabular}

${ }^{a} \mathrm{MRD}_{\mathrm{a}}=1: 2 ; \mathrm{MRD}_{\mathrm{s}}=1: 4$.

${ }^{b}$ Communicable Disease Center, Atlanta, Ga.

2 and 3 histoplasmin (agar-gel) precipitin antigen was established as a $1: 2$ and $1: 4$ dilution, respectively.

Serum titrations. The inhibition, or indirect, method was used in titrating unknown serum specimens. Serial twofold dilutions of $0.2 \mathrm{ml}$ of unknown serum were made in physiological saline. To each dilution, $0.2 \mathrm{ml}$ of the previously box-titered antigen $\mathrm{MRD}_{a}$ was added; the final mixture thus contained $1 / 2 \mathrm{MRD}_{a}$ plus unknown serum dilutions ranging from $1: 2$ to 1:32. The mixtures were hand shaken for $10 \mathrm{sec}$ and were incubated in a water bath $(37 \mathrm{C})$ for $30 \mathrm{~min}$ to permit antigen-antibody binding to proceed to completion.

Each of the wells in the center row of agar diffusion plates was filled with a $\mathrm{MRD}_{\mathrm{B}}$ of the positive histoplasmosis human control serum, and the plates were incubated at room temperature $(23$ to $27 \mathrm{C})$ for $1 \mathrm{hr}$. Conclusions of incubation periods for the plates and for the antigen-antibody binding mixture were timed to coincide and permit immediate completion of the final step.

Outer rows of wells were filled sequentially and in duplicate with the incubated antigen-serum dilution mixtures. Thus, each well in one outer row contained the same mixture as the corresponding well in the opposite outer row. The end point, or titer, of an unknown positive serum was the dilution that completely inhibited the formation of a visible line of precipitate with the box-titered $\mathrm{MRD}_{a}$ and $M R D_{\mathrm{s}}$ in the agar-gel plates (Fig. 1).

Controls subjected to the same test procedure consisted of dilutions of the test antigen in saline and combinations of the predetermined $\mathrm{MRD}_{a}$ of antigen with negative and positive histoplasmosis sera.

Agar-plate precipitin test for histoplasmosis. The direct diffusion agar-plate precipitin test for histoplasmosis described by Schubert, Lynch, and Ajello (9) was performed in the agar-gel plates previously described for use in the AGPI test. This allowed similar conditions of diffusion for the Histoplasma antigen and antibody comparative evaluation (Fig. 2).

CF test for histoplasmosis. When the CF test was performed on serum specimens, the procedure used was that described by Smith et al. (11). The overnight fixation procedure and $100 \%$ fixation end point were employed in these CF determinations. 
The Histoplasma mycelial- and yeast-phase antigens and the positive human CF control serum were obtained from the Diagnostic Reagents Section, Communicable Disease Center, Atlanta, Ga., and were from lots 23,31 , and 22 , respectively.

\section{RESULTS}

The AGPI test sensitivity was initially determined on serial sera from two human cases of histoplasmosis and a positive human CF control serum (Table 3 ). In addition, positive human $\mathbf{C F}$

TABLE 2. Histoplasmosis antigen-antibody agar-gel box titration ${ }^{a}$

\begin{tabular}{c|c|c|c|c|c}
\hline \multirow{2}{*}{$\begin{array}{c}\text { Lot } 22 \mathrm{CDC}^{0} \\
\text { human control } \\
\text { dilution }\end{array}$} & \multicolumn{5}{|c}{ Lot 3 precipitin antigen dilution } \\
\cline { 2 - 5 } & $1: 2$ & $1: 4$ & $1: 8$ & $1: 61$ & $1: 32$ \\
\hline $1: 2$ & + & + & \pm & - & - \\
$1: 4$ & + & + & \pm & - & - \\
$1: 8$ & + & \pm & - & - & - \\
$1: 16$ & \pm & - & - & - & - \\
$1: 32$ & - & - & - & - & - \\
\hline
\end{tabular}

${ }^{a} \mathrm{MRD}_{\mathrm{a}}=1: 4 ; \mathrm{MRD}_{\mathrm{s}}=1: 4$.

${ }^{b}$ Communicable Disease Center, Atlanta, Ga. control sera from cases of coccidioidomycosis and blastomycosis were used as negative controls. These serum results were positive and negative, respectively, when the agar-plate precipitin test of Schubert et al. (9) was used (Fig. 2).

To obtain titers, it was necessary to perform a box titration of the antigen-antibody system. Serial dilutions of precipitin antigen (lot 2) were reacted in agar-gel plates with serial dilutions of human positive histoplasmosis CF control serum (lot 13). These dilutions were added to the agargel plates simultaneously, and incubated at room temperature for an observation period of $48 \mathrm{hr}$; additional incubation did not enhance the precipitin line formation. The results recorded at $\mathbf{4 8}$ $\mathrm{hr}$ are shown in Table 1. Thus, the derivation of the MRD of each reactant was obtained and could be applied to the titration of the positive histoplasmosis human sera in the AGPI technique. It was noticed, however, that the line of precipitate was relatively close to the antiserum or antibody well. To obtain a reaction equidistant between these antigen and antibody wells, it was necessary to prediffuse the $\mathrm{MRD}_{\mathrm{s}} 1 \mathrm{hr}$ prior to the addition of the unknown serum $\leftarrow M R D_{a}$ mixture in performing the test.

TABLE 3. Serological comparison of human and animal histoplasmosis serum specimens

\begin{tabular}{|c|c|c|c|c|c|c|c|c|}
\hline \multirow{2}{*}{$\begin{array}{c}\text { Fig. } 2 \\
\text { no. }\end{array}$} & \multirow{2}{*}{ Serum } & \multicolumn{2}{|c|}{ Source CF titer ${ }^{a}$} & \multicolumn{2}{|c|}{ FDSL CF titer ${ }^{a}$} & \multicolumn{2}{|c|}{ AGPI titer ${ }^{a}$} & \multirow{2}{*}{$\begin{array}{l}\text { Agar-plate } \\
\text { precipitin }\end{array}$} \\
\hline & & Mycelial & Yeast & Mycelial & Yeast & Lot 2 & Lot 3 & \\
\hline c & $\begin{array}{l}\text { Positive } \\
\text { coccidioi- } \\
\text { domycosis } \\
\text { human } \\
\text { serum }\end{array}$ & $\begin{array}{l}\text { Histo- } \\
\text { plasmo- } \\
\text { sis } \\
\text { negative }\end{array}$ & $\begin{array}{l}\text { Histo- } \\
\text { plasmo- } \\
\text { sis } \\
\text { negative }\end{array}$ & $\begin{array}{l}\text { Histo- } \\
\text { plasmo- } \\
\text { sis } \\
\text { negative }\end{array}$ & $\begin{array}{l}\text { Histo- } \\
\text { plasmo- } \\
\text { sis } \\
\text { negative }\end{array}$ & Negative & Negative & Negative \\
\hline c & $\begin{array}{l}\text { Positive } \\
\text { blastomy- } \\
\text { cosis hu- } \\
\text { man serum }\end{array}$ & Negative & Negative & Negative & Negative & Negative & Negative & Negative \\
\hline 1 & O.G. & 16 & 16 & 20 & 5 & 8 & 16 & + \\
\hline 2 & V.O. & 256 & 64 & 40 & 40 & 512 & 1,024 & + \\
\hline 3 & H.Y. ${ }^{b}$ & N.T. ${ }^{c}$ & 512 & 320 & 320 & 512 & 512 & + \\
\hline 4 & H.M. ${ }^{b}$ & 128 & N.T. ${ }^{c}$ & 40 & 80 & 256 & 512 & + \\
\hline 5 & F.T.-1 & 32 & 32 & 10 & 40 & 32 & 32 & + \\
\hline 6 & F.T. -2 & N.A. ${ }^{d}$ & N.A. ${ }^{d}$ & 5 & 40 & 32 & 32 & + \\
\hline 7 & F.T. -3 & N.A. ${ }^{d}$ & N.A. ${ }^{d}$ & 5 & 40 & 32 & 32 & + \\
\hline 8 & F.T. -4 & 32 & 32 & 10 & 40 & 32 & 64 & + \\
\hline 9 & F.T. -5 & 16 & 16 & 10 & 80 & 32 & 32 & + \\
\hline 10 & F.H.-1 & 16 & 16 & 5 & 10 & 16 & 32 & + \\
\hline 11 & F.H.-2 & 16 & 16 & 5 & 10 & 32 & 32 & + \\
\hline 12 & F.H. -3 & N.A. ${ }^{d}$ & N.A. ${ }^{d}$ & 5 & 20 & 64 & 64 & + \\
\hline 13 & F.H. -4 & N.A. ${ }^{d}$ & N.A. ${ }^{d}$ & 5 & 20 & 32 & 64 & + \\
\hline 14 & F.H. -5 & N.A. ${ }^{d}$ & N.A. ${ }^{d}$ & 5 & 20 & 64 & 64 & + \\
\hline
\end{tabular}

a All titers are reported as reciprocal titers.

${ }^{b}$ Rabbit sera. Inoculation with Histoplasma yeast-phase (HY) and mycelial-phase (HM) antigens.

c Not tested.

d Not available from hospital records. 
When the lot 2-lot 13 antigen-antibody MRD system (Table 1) was used, titers of the tested serum samples were obtained as shown in Table 3 (AGPI titers lot 2). To ascertain the degree of reproducibility of this antigen-antibody system in the AGPI technique, lot 3 and lot 22 of histoplasmosis precipitin antigen and human positive CF control serum, respectively, were obtained, and a similar box titration was performed; final results are shown in Table 2 . The same sera were assayed with the use of the MRD of lot 3 and lot

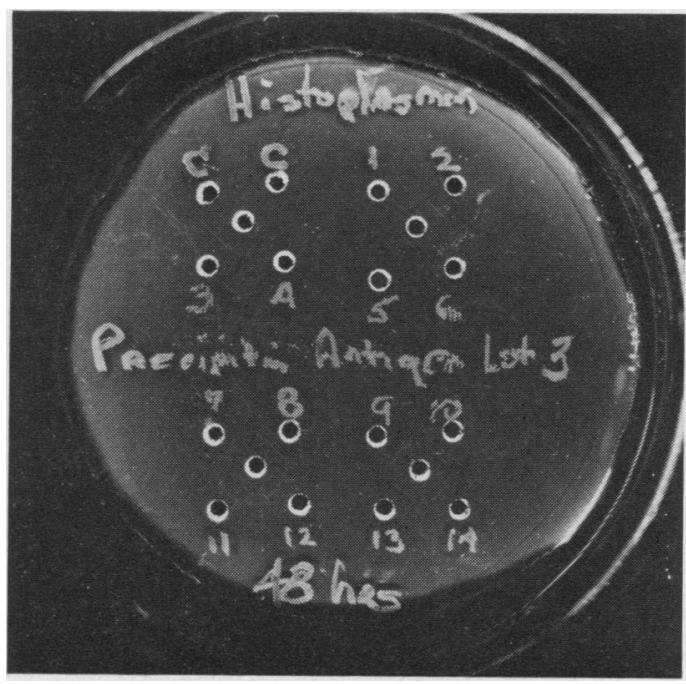

FIG. 2. Direct diffusion agar-plate precipitin test for histoplasmosis. Note lines of precipitate between center and outer walls. Numbers correspond to those serum specimens reported in Table 3. Results were noted at $48 \mathrm{hr}$ of room-temperature incubation.
22 in the agar-gel precipitin-inhibition technique; the results are depicted in Table 3 (AGPI titers lot 3). This indicated the degree of sensitivity and reproducibility of this test antigen-antibody system in histoplasmosis serology compared with different lots of precipitin antigen and positive control serum. The AGPI test also provides a titration end point of each histoplasmosis-positive human serum specimen; this cannot be obtained by the agar-plate precipitin test.

The CF test was performed on these same serum specimens (Table 3), by use of the mycelial and yeast phases of $H$. capsulatum antigenic determinants. It is interesting to note that the titers of these sera by the Fort Detrick Serological Laboratory (FDSL) $100 \%$ CF method correlated with the serum source CF titers and that each serum had titers to antigens of both phases of $H$. capsulatum. The $100 \%$ FDSL CF method, however, evidenced greater variation in titer response to the two antigenic phases of $H$. capsulatum than the source CF method. The AGPI titers generally exceeded those attained by either CF test.

Recently, three human sera obtained from $M$. Furcolow's laboratory through the courtesy of John Converse proved to be very interesting (serum numbers 1, 2, and 3, Table 4). These were aberrant sera in that sera 1 and 2 were not positive by the agar-plate method of Schubert et al. (9) nor by the FDSL CF techniques; however, serum 3 showed anticomplementary activity by the latter test. These sera, in addition to control sera from the previous experiment (Table 3, sera $2,3,4$, and 5), were diffused in the agar-gel plate against the mycelial-phase, yeast-phase, and precipitin (agar-gel) antigens of $H$. capsulatum. The developing reactions were observed after 24,48 ,

TABLE 4. Serological comparison of aberrant and control histoplasmosis serum specimens

\begin{tabular}{|c|c|c|c|c|c|c|c|c|c|c|}
\hline \multirow{2}{*}{$\begin{array}{l}\text { Fig. } 3 \\
\text { no. }\end{array}$} & \multirow{2}{*}{ Serum } & \multicolumn{2}{|c|}{ Source CF titer ${ }^{a}$} & \multicolumn{2}{|c|}{ FDSL CF titer $^{a}$} & \multicolumn{2}{|c|}{ AGPI titer $^{a}$} & \multicolumn{3}{|c|}{$\begin{array}{l}\text { Agar-plate pre- } \\
\text { cipitin test }{ }^{b}\end{array}$} \\
\hline & & Mycelial & Yeast & Mycelial & Yeast & Lot 2 & Lot 3 & MP & PtP & YP \\
\hline 1 & Blaine $^{c}$ & Negative & 32 & Negative & Negative & 2 & 2 & - & - & - \\
\hline 2 & $S \cot t^{c}$ & 64 & Negative & 10 & Negative & 32 & 32 & + & - & + \\
\hline 3 & Land $c$ & 32 & 64 & $\mathrm{AC}^{d}$ & $\mathrm{AC}^{d}$ & 32 & 32 & - & + & - \\
\hline 4 & Lot $22, c$ HHC & 16 & 64 & Negative & Negative & 128 & 64 & - & + & - \\
\hline 5 & F.T.-1, 1-20-65 & 32 & 32 & 10 & 40 & 32 & 32 & - & + & - \\
\hline 6 & V.O. & 256 & 64 & 40 & 40 & 512 & 1,024 & - & + & - \\
\hline 7 & H.Y. & N.T.e & 512 & 320 & 320 & 512 & 512 & + & + & + \\
\hline 8 & H.M. & 128 & N.T.e & 40 & 80 & 256 & 512 & - & + & - \\
\hline
\end{tabular}

a All titers are reported as reciprocal titers.

${ }^{b} \mathrm{MP}, \mathrm{PtP}$, and YP $=$ mycelial-phase, precipitin, and yeast-phase antigens, respectively.

c Aberrant serum.

d Anticomplementary serum.

- Not tested. 
$72,96,120$, and $144 \mathrm{hr}$ of incubation at room temperature. Table 4 shows the results of these serum reactions with the respective antigens after $72 \mathrm{hr}$ of incubation, as well as their titers by the source and FDSL CF techniques. Figure 3 shows the precipitin reaction. It is significant that serum 7 (Fig. 3) reacted with the precipitin agar-plate antigen with four lines of precipitate, two lines of precipitate with the mycelial phase antigen, and one diffuse line of precipitate with the yeast-phase
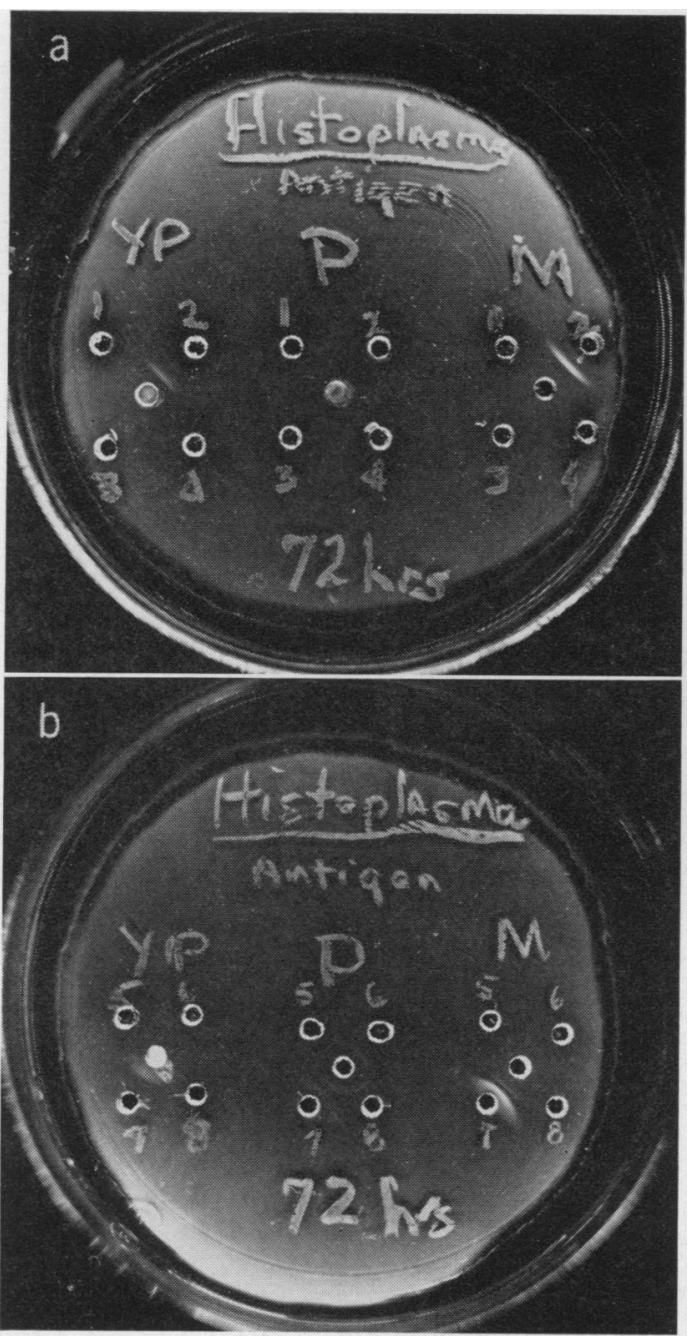

Fig. 3. Aberrant versus control serum precipitin reactions for histoplasmosis after $72 \mathrm{hr}$. (a) Aberrant sera 1, 2, 3, and 4 (Table 4) diffused in agar-gel against the yeast-phase $(Y P)$, histoplasmin (agar-gel) precipitin (P), and mycelial-phase $(M)$ antigens. (b) Control sera 5, 6, 7, and 8 (Table 4) diffused in agar-gel against the same antigen sequence.
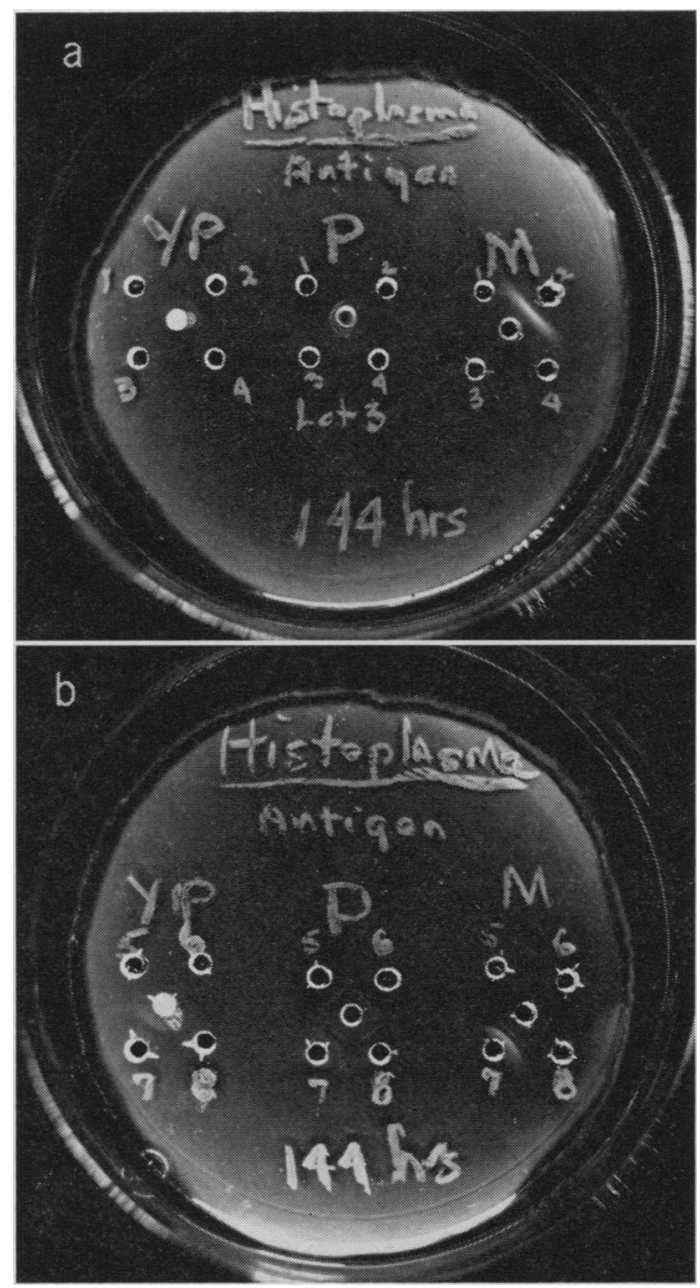

FIG. 4. Aberrant versus control serum precipitin reactions for histoplasmosis after 144 hr. (a) Aberrant sera 1, 2, 3, and 4 (Table 4) diffused in agar-gel against the yeast-phase $(Y P)$, histoplasmin (agar-gel) precipitin $(P)$, and mycelial-phase $(M)$ antigens. (b) Control sera 5, 6, 7, and 8 (Table 4) diffused in agar-gel against the same antigen sequence.

antigen of $H$. capsulatum. This same serum also reacted with serum 5 irrespective of the antigen wells, indicating the presence of antihuman serum antibodies in this serum.

After $144 \mathrm{hr}$ of incubation at room temperature, sera 1, 2, 3, and 4 had developed an extra line of precipitate close to the agar-gel precipitin test antigen well (Fig. 4) that was not observed at the same reactive time with sera $5,6,7$, and 8 . This observation indicates a complexity of antigen-antibody reactions in agar-gel to the various tested Histoplasma standard antigens and will 
necessitate further investigation of these systems to classify the observed lines.

\section{Discussion}

The agar-gel test for histoplasmosis described by Schubert, Lynch, and Ajello (9), and later evaluated with other serological tests for clinical diagnosis of this disease by Schubert and Wiggins (10), correlated 90 to $100 \%$ with the mycelialphase histoplasmin CF results. Unfortunately, serum titration end points cannot be obtained by this method.

The results of this experiment indicate that the AGPI procedure can determine titers in positive Histoplasma sera similar to those attained by the CF method. In addition, serum specimens that are anticomplementary by the $\mathrm{CF}$ procedure can be titrated in the AGPI test to their end point, since this test does not depend on complement for its activity. Thus, the AGPI test eliminates the necessity for standardization of complement and the use of a sheep-cell indicator system.

The AGPI procedure, when compared with the agar-plate direct diffusion test for the detection of Histoplasma antibodies, shows a greater sensitivity because low-titered positive sera cannot be detected by the direct method. Probably this is due to the fact that there is insufficient antibody in the serum specimen to precipitate enough antigen for the formation of a visible precipitin line by the direct diffusion method.

The advocated AGPI procedure derives its sensitivity in determining Histoplasma antibodies from inhibition of the minimal reacting dilutions of a soluble, diffusible antigen-antibody system that is predetermined by a box titration of the reacting reagents in agar-gel plates. Variations in batch lots of the $H$. capsulatum antigen or in the antibody content of any known positive serum are minimized by this box titration.

The results of this investigation also indicate the necessity for a definitive study of the various antigen-antibody systems of Histoplasma in agar-gel. This is essential for the determination of the role played by the mycelial-phase, yeast-phase, and precipitin serological antigens in the serodiagnosis of histoplasmosis.

\section{ACKNOWLEDGMENTS}

Acknowledgment is made of the technical assistance of Maurice M. Mount, Jr., and to the Photo- graphic Section at Fort Detrick for the figures presented in this paper. Special acknowledgment is conveyed to John L. Converse for obtaining aberrant serum specimens from Dr. Larsh and Dr. Furcolow's laboratory; to John Bennett of the National Institutes of Health for contributing serial serum specimens of two human histoplasmosis cases; to Kenneth E. Hanson, U.S. Public Health Service, for obtaining the test antigens, and to Paul J. Kadull for his aid in preparation of this manuscript.

\section{Literature Cited}

1. Campbell, C. C., and G. E. Binkley. 1953. Serologic diagnosis with respect to histoplasmosis, coccidioidomycosis and blastomycosis, and the problem of cross reactions. J. Lab. Clin. Med. 42:896-906.

2. Goldin, M., AND S. MCMillen. 1963. A micromethod for the agar-gel precipitin test for histoplasmosis. Am. Rev. Respirat. Diseases 87:592-593.

3. Heiner, D. C. 1958. Diagnosis of histoplasmosis using precipitin in agar-gel. Pediatrics 22 :616627.

4. Kaufman, L., B. Brandt, and D. Mclaughlin. 1964. Evaluation of the fluorescent antibody and agar-gel precipitin tests for detecting Histoplasma antibodies in anticomplementary sera. Am. J. Hyg. 79:181-185.

5. KLITE, P. D. 1965. The interpretation of agar-gel precipitin reactions in histoplasmosis. J. Lab. Clin. Med. 66:770-787.

6. RaY, J. G., JR., AND P. J. Kadull. 1964. The agar-gel precipitin technique in anthrax antibody determinations. Appl. Microbiol. 12:349354.

7. Ray, J. G., JR., AND P. J. KadUll. 1965. Agar-gel precipitin-inhibition technique for plague antibody determinations. Appl. Microbiol. 13:925930.

8. RAY, J. G., JR., AND D. E. Shay. 1965. Agar-gel precipitin-inhibition technique for C-reactive protein determinations. Appl. Microbiol. 13:301-304.

9. Schubert, J. H., H. J. LynCh, and L. Ajello. 1961. Evaluation of the agar-plate precipitin test for histoplasmosis. Am. Rev. Respirat. Diseases 84:845-849.

10. Schubert, J. H., AND G. L. Wiggins. 1963. The evaluation of serologic tests for histoplasmosis in relation to the clinical diagnosis. Am. J. Hyg. $77: 240-249$.

11. Smith, C. E., M. T. Satto, R. R. Beard, R. M. KePp, R. W. Clark, and B. U. Eddie. 1950. Serological tests in the diagnosis and prognosis of coccidioidomycosis. Am. J. Hyg. 52:1-21. 